\title{
COMPARATIVE STUDY OF THE FORCES IN G+5 AND G+10 MULTI STORIED BUILDINGS SUBJECTED TO DIFFERENT WIND SPEEDS
}

\author{
N. Ramakrishna ${ }^{1}$, G. Papa Rao $^{2}$, P Veerabhadra Rao $^{3}$ \\ ${ }^{l}$ P.G Student, Department of Civil Engineering, GayatriVidyaParishad College of Engg, Visakhapatnam, India- \\ 530048 \\ ${ }^{2}$ Associate Professor, Department of Civil Engg, GayatriVidyaParishad College of Engg., Visakhapatnam, India- \\ 530048 \\ ${ }^{3}$ Professor, Department of Civil Engg, GayatriVidyaParishad College of Engg., Visakhapatnam, India - 530048
}

\begin{abstract}
The objective of this paper is to analyze and compare the forces in $G+5$ and $G+10$ multi storied buildings for different wind speeds of 180,200,220, 240 and $260 \mathrm{kmph}$ having a height of 20m and 35m using ETABS as per Indian standards. This study shows how the beam and column design is affected by the height of the building. Comparison of volume of concrete and quantity of steel is done for the whole building and also comparisons made for the internal forces like support reactions, bending moment, beam sizes, column sizes, percentage of reinforcement for different wind speeds. Also the lateral storey displacements, story shears and storey drifts are analyzed for the above wind speeds of the same structure.
\end{abstract}

Keywords: Wind effect, Multi storied building, Storey displacements, Support reactions, ETABS. ****

\section{INTRODUCTION}

The air motion relative to the earth surface is called wind. Indian wind code stipulates that, thewind load parameters of buildings and structure such as probability based design wind speed, terrain and height effect, gust load factor, pressure and force coefficients are to be considered to calculate wind loads for design. As per Indian standards, the wind speed more than $80 \mathrm{kmph}$ is called very strong winds associated with cyclonic storms, thunder storms, dust storms or vigorous monsoons. Even though for coastal regions like Visakhapatnam, the code gives the guide line to take the basic wind speed of $50 \mathrm{~m} / \mathrm{s}(180 \mathrm{kmph})$ in the view of cyclone resistant design. But recently, the cyclone Hud-Hud experienced the wind speed of $220 \mathrm{kmph}$ as recorded by anemometers. Similarly in 1996 also, the wind speed of $230 \mathrm{kmph}$ affects the coastal regions very severely. However in India, the cyclones occurs periodically is becoming one of the major disastrous things for the damage of the property. For reducing this damage, it is necessary to consider the higher wind speeds in the design of structures. Now wind speed of around $250 \mathrm{kmph}$ and above should be kept in mind while making structural designs. In this context, an attempt has been made to studyand compare how the support reactions, column reinforcements and beam reinforcements, lateral storey displacements, story shears and storey drifts lateral storey displacements, story shears and storey drifts varying with different wind speeds.

\section{METHODOLOGY}

In reinforced concrete construction the wind effect in the multi storied building has played an important role. Sometimes, it may happen to change the mind to allow or not to allow wind loading in the structure. In non-sway buildings, wind loading will be resisted by the beams and the columns of the building which have to be designed considering the wind loading. For analysis purpose, multi storeyed buildings of length $16 \mathrm{~m}$, width $16 \mathrm{~m}$, and height of $20 \mathrm{~m}$ and $35 \mathrm{~m}$ is considered. The structural properties of the building considered are taken as

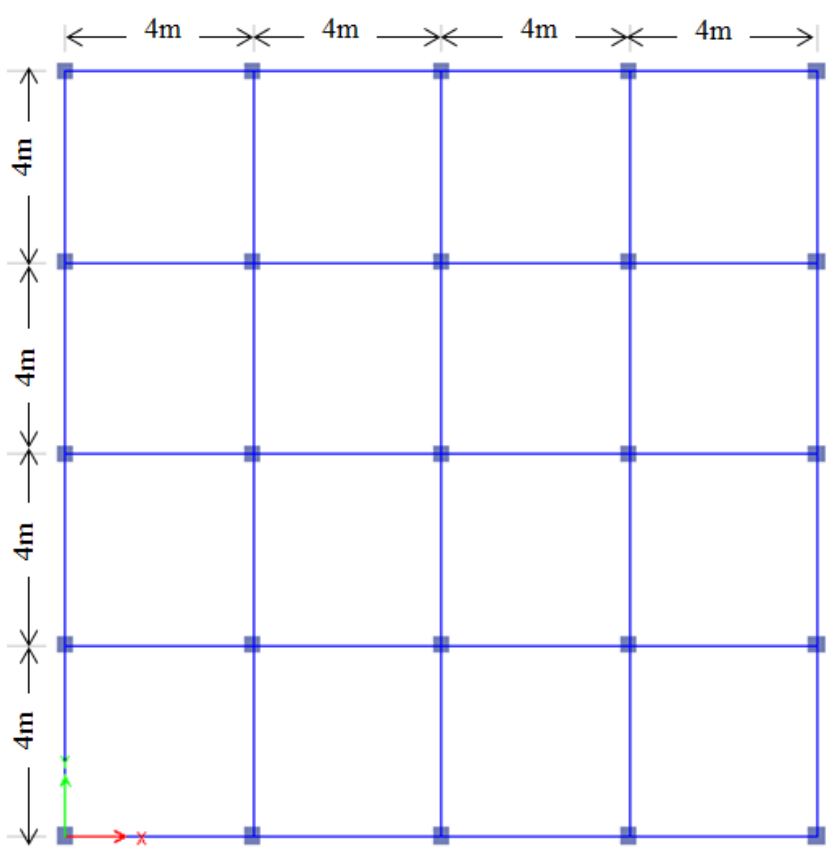

Fig 1: Plan of the building
All columns
All columns
$=300 \mathrm{~mm} \times 300 \mathrm{~mm}($ For $\mathrm{G}+5$ building $)$
Plinth beams
$=400 \mathrm{~mm} \times 400 \mathrm{~mm}($ For $\mathrm{G}+10$ building $)$
Floor beams
$=300 \mathrm{~mm} \times 400 \mathrm{~mm}$
Slab thickness is $=150 \mathrm{~mm}$
Grade of concrete $=\mathrm{M} 25$ 
Grade of steel $=\mathrm{Fe} 415$

Live load on slab $=2 \mathrm{kN} / \mathrm{m}^{2}$

Exterior wall load $\quad=12 \mathrm{kN} / \mathrm{m}$

Interior wall load $=6 \mathrm{kN} / \mathrm{m}$

In ETABS the wind load is applied as:

Wind Load as per IS: 875(part 3) - 1987

Structure class : $\quad$ Class B(greatest

horizontal/vertical dimension between 20 to $50 \mathrm{~m}$ )

Terrain category : 2 (open terrain with obstructions 1.5 to

$10 \mathrm{~m}$, adjacent to sea coast)

Wind speed

$180,200,220,240,260$

kmph(i.e., 50, 55.56, 61.12, 66.67, 72.23m/s)

Risk coefficient $\mathrm{k}_{1}$
Topography factor $\mathrm{k}_{3} \quad: 1$

Pressure coefficient $\quad: 0.8$ (wind ward side).

Load combinations considered are:

$1.5 \mathrm{DL}+1.5 \mathrm{LL}$

1.2DL+1.2LL $\pm 1.2 \mathrm{WLX}$

1.2DL+1.2LL $\pm 1.2 \mathrm{WLY}$

1.5DL $\pm 1.5 \mathrm{WLX}$

$1.5 \mathrm{DL} \pm 1.5 \mathrm{WLY}$

$0.9 \mathrm{DL} \pm 1.5 \mathrm{WLX}$

$0.9 \mathrm{DL} \pm 1.5 \mathrm{WLY}$

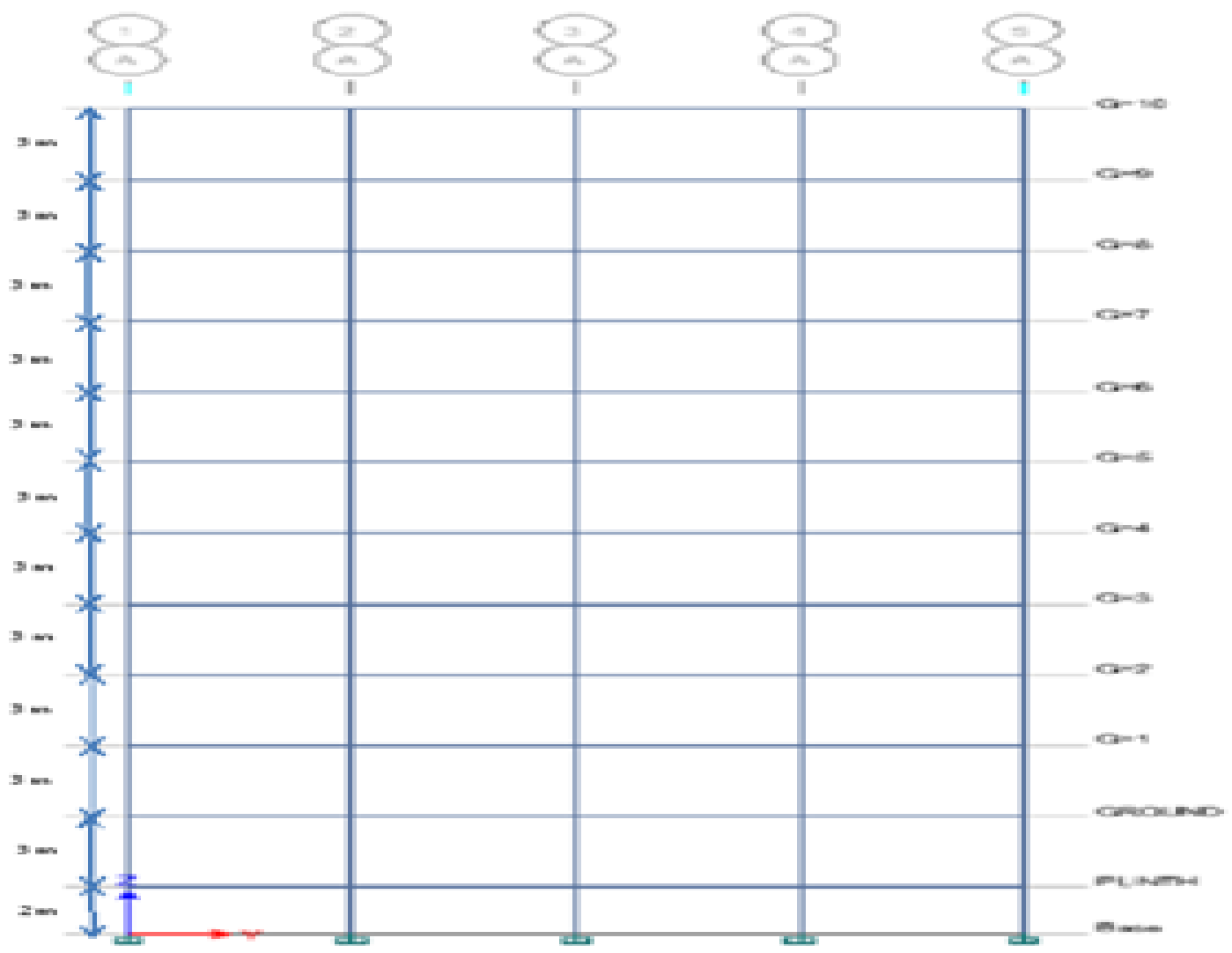

Fig 2: Elevation of $\mathrm{G}+10$ building

The column cross section is insufficient for the wind speed greater than $220 \mathrm{kmphafter}$ analysis of support reactions, column cross sections are revised to $350 \mathrm{~mm} \times 350 \mathrm{~mm}$ for $\mathrm{G}+5$ and $450 \mathrm{~mm} \times 450 \mathrm{~mm}$ for G+10building. The reinforcement is designed for those revised sections.

\section{ANALYSES AND DISCUSSION OF RESULTS}

The wind load for the wind speeds 180, 200, 220, 240, $260 \mathrm{kmph}$ are analysed for regular and symmetrical multi storied buildings $\mathrm{G}+5$ and $\mathrm{G}+10$. For these structures only the wind load is changed making other loads are constant. The variation of support reactions, lateral storey displacements, column reinforcement, beam reinforcement and storey drifts are analysed with the variation of wind speeds for the same structure.

\subsection{Support Reactions:}

The change in exterior column support reactions is more compared to edge columns. Similarly the change in interior columns is very less. The change of support reactions in edge and interior columns is not much differing to change the footing design. However, the change in exterior columns influences the change of footing design. 


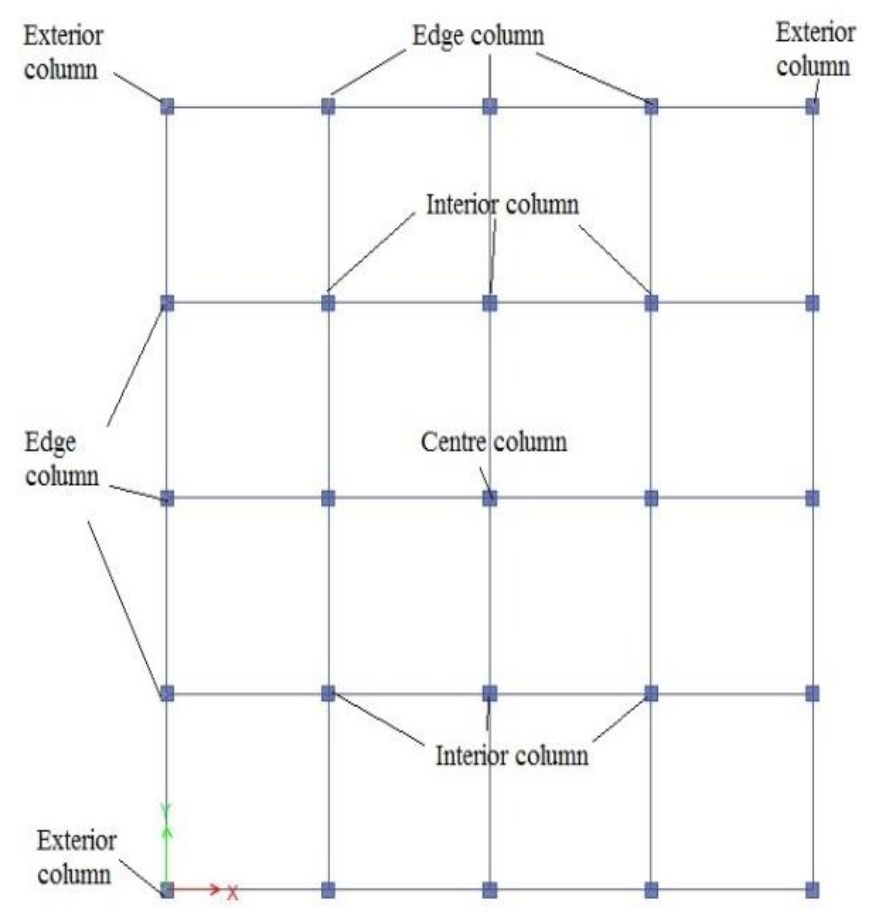

Fig 3: Plan of building with column notations

According to Table 1, in G+5 building; exterior columns the support reactions is increased by 8 to $16.5 \%$. In edge columns the support reactions is increased by 5.5 to $11.5 \%$. In interior columns the support reactions is increased by 0.6 to $1.2 \%$ compared to gravity loading (without wind load). No change in center column support reaction but the increase in moment due to lateral load is observed.

According to Table 2, in G+10 building; exterior columns the support reactions is increased by 13.5 to $28.2 \%$. In the edge columns the support reactions is increased by 10 to $22 \%$. In interior columns the support reactions is increased by 0.4 to $0.9 \%$ compared to gravity loading (without wind load). No change in center column support reaction but the increase in moment due to lateral load is observed.

According to Table 3 , in $\mathrm{G}+5$ building, the variation of support reactions in exterior columns increased by $8 \%$ and in edge columns increased by $5.5 \%$ in interior columns increased by $1.5 \%$ for wind speed $260 \mathrm{kmph}$ when compared with $180 \mathrm{kmph}$ wind speed. In $\mathrm{G}+10$ building, the variation of support reactions in exterior columns increased by $13 \%$ and in edge columns increased by $10 \%$ in interior columns increased by $0.5 \%$ for wind speed $260 \mathrm{kmph}$ when compared with $180 \mathrm{kmph}$ wind speed.

\section{COLUMN REINFORCEMENT}

In $\mathrm{G}+5$ building, the percentage variation of steel in edge, exterior and interior columns varies from 1.2-4.22\%, 2.1$6.29 \%, 2.9-5.88 \%$ between gravity loads to wind loads for wind speed $260 \mathrm{kmph}$ respectively in ground floor for the column size of $300 \mathrm{~mm} \times 300 \mathrm{~mm}$. For the columns $\mathrm{G}+2$ level and above, the nominal reinforcement percentage of $0.8 \%$ is sufficient including wind effect. The exterior columns should be designed for $3.24 \%$ reinforcement for the same structure for wind speed $220 \mathrm{kmph}$ which designed for $2.4 \%$ reinforcement for wind speed $180 \mathrm{kmph}$. If the design wind speed is more than $220 \mathrm{kmph}$ then the column section is insufficient. For the modified cross section of column the reinforcement required is shown in Table 4.

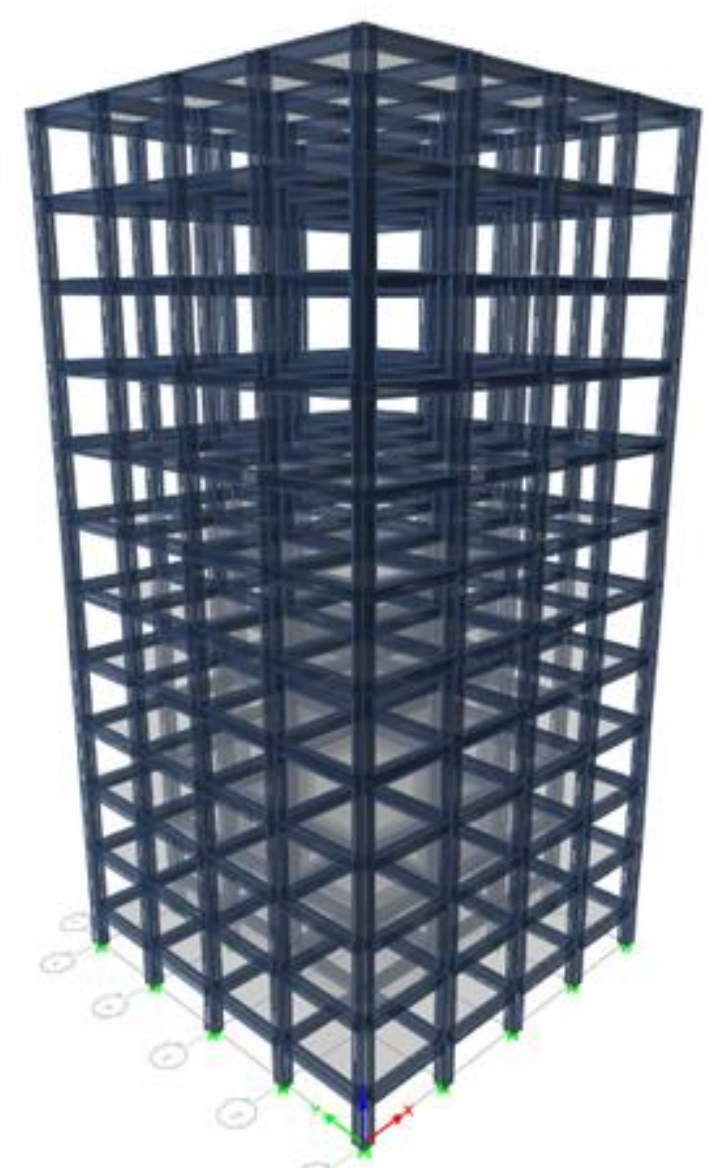

Fig 4: Three dimensional extruded view of $\mathrm{G}+10$ building

Similarly, in G+10 building for fifth storey, the percentage variation of steel in edge, exterior and interior columns varies from $0.8-3.24 \%, 1.24-3.88 \%, 1.8-3.53 \%$ between gravity loads to wind load for speed $260 \mathrm{kmph}$ respectively for the column size of $400 \mathrm{~mm} \times 400 \mathrm{~mm}$. If the design wind speed is more than $220 \mathrm{kmph}$ then the column section is insufficient.

In the external and internal beams, the percentage of bottom middle reinforcement is same for both wind and gravity load design. It is also observed that the reinforcement required for beams increases from top storey to bottom storey i.e., the steel required for 3rd storey beams is higher than the 4th storey beams.

It is observed that when wind speed exceeds $220 \mathrm{kmph}$ the edge columns subjected to high design moments compared to low wind speeds. So, the percentage of steel reinforcement is more than the interior columns. Here 1.5DL+1.5WL load combination govern the column design. 


\section{STOREY DISPLACEMENTS:}

In $\mathrm{G}+5$ building; the lateral storey displacement for the basic wind speed $180 \mathrm{kmph}$ is $15.6 \mathrm{~mm}$, whereas for the wind speed $260 \mathrm{kmph}$ it is $32.7 \mathrm{~mm}$ in 5 th floor. If the wind speed is constant the lateral displacement not that much noticeable, if it is varying rapidly then it turns the cracks the columns from minor to major and finally to the failure stage.Here the structure is $\mathrm{G}+5$ building so the wind effect in the storey displacement is not that much important in the design point view but, for $\mathrm{G}+10$ building it should be considered. Usually shear walls are added for the high rise buildings to carry lateral loads.

In $\mathrm{G}+10$ building; the lateral storey displacement for the basic wind speed $180 \mathrm{kmph}$ is $36.9 \mathrm{~mm}$, whereas for the wind speed $260 \mathrm{kmph}$ it is $77 \mathrm{~mm}$ for 10 th floor. The value is more than $200 \%$. So, suitable measures are required to reduce lateral storey displacements.

\subsection{Storey Drifts}

Storey drift is the lateral displacement of one level of a multi storeyed building relative to the level below. Storey drift values that greater than 0.025 is serious threat to the human safety in structures. The storey drifts are with in permissible limits. It is observed that in G+5 building, the drift is more at ground floor to first floor and in $\mathrm{G}+10$ building the drift is more in ground floor.

\subsection{Comparison of Concrete and Steel in Footings}

The volume of concrete in exterior column footing increased as $18,24.14$ and $32.95 \%$ for $180,200,220 \mathrm{kmph}$ wind speeds with respect to gravity in 5 storied building where as in 10 storied building 34.73, 44.72 and $54.43 \%$.

The volume of concrete in edge column footing in $\mathrm{X}$ direction increased as $7.23,9.40$ and $11.93 \%$ for three different wind speeds with respect to gravity in 5 storied building where as in 10 storied building 9.89, 13.38 and $15.37 \%$. The volume of concrete in edge column footing in $Y$ direction increased as $14.09,18.50$ and $21.81 \%$ for three different wind speeds with respect to gravity in 5 storied building where as in 10 storied building 24.35, 31.7 and $36.64 \%$. However the variation is very small in interior column footings. It is observed that the weight of steel in edge column in $\mathrm{X}$ direction footings between gravity loads to three different wind speeds varies as $7.46,13.15$ and $18.91 \%$ in 6 storied building and 12.82, 14.06 and $17.99 \%$ in 15 storied building respectively.

It is observed that the weight of steel in edge column in $\mathrm{Z}$ direction footings between gravity loads to three different wind speeds varies as $16.79,21.25$ and $25.39 \%$ in 5 storey building and 36.69, 47.08 and $53.05 \%$ in 10 storeyed building respectively.

It is observed that the percentage variation of cost for the whole structure, between gravity load and three different wind speeds varies as 4.98, 5.56 and $6.62 \%$ in 5 storey building and 9.82, 11.89 and $13.52 \%$ in $\mathrm{G}+10$ building respectively.

\subsection{Storey Shears:}

The storey shears due to wind loads increases gradually due to increase of lateral load. The results shows that increase of $200 \%$ for wind speed of $260 \mathrm{kmph}$ compared with $180 \mathrm{kmph}$. The analysis gives that for the wind speed more than $220 \mathrm{kmph}$ the design combination should be 1.5 times dead load and wind load.

\subsection{Support Reactions:}

Table 1: Comparison of support reactions for different wind speeds of G+5:-

\begin{tabular}{|c|c|c|c|c|c|c|c|c|c|c|c|c|}
\hline \multirow{3}{*}{$\begin{array}{l}\text { S. } \\
\text { No. }\end{array}$} & \multirow{3}{*}{$\begin{array}{l}\text { Location } \quad \text { of } \\
\text { column }\end{array}$} & \multicolumn{6}{|c|}{ Support reaction $(\mathrm{kN})$ for different wind speeds } & \multirow{2}{*}{\multicolumn{5}{|c|}{$\begin{array}{l}\text { Increase of support reactions } \\
\text { variation in percentage for wind } \\
\text { speeds }\end{array}$}} \\
\hline & & \multirow{2}{*}{\begin{tabular}{|l} 
DL+LL \\
$\mathbf{0}$
\end{tabular}} & \multicolumn{5}{|c|}{$\mathrm{DL}+\mathrm{LL}+\mathrm{WL}$} & & & & & \\
\hline & & & 180 & 200 & 220 & 240 & 260 & 180 & 200 & 220 & 240 & 260 \\
\hline 1 & $\begin{array}{l}\text { Exterior } \\
\text { columns }\end{array}$ & 637.32 & 687.51 & 699.41 & 712.51 & 726.63 & 742.25 & 7.87 & 9.74 & 11.8 & 14.01 & 16.46 \\
\hline 2 & $\begin{array}{ll}\text { Edge } & \text { side } \\
\text { columns } & \\
\end{array}$ & 922.42 & 972.65 & 984.52 & 997.65 & 1011.81 & 1027.4 & 5.44 & 6.73 & 8.16 & 9.70 & 11.38 \\
\hline 3 & $\begin{array}{l}\text { Edge middle } \\
\text { columns }\end{array}$ & 933.86 & 984.11 & 995.91 & 1009.05 & 1023.01 & 1038.86 & 5.37 & 6.64 & 8.05 & 9.54 & 11.24 \\
\hline 4 & $\begin{array}{l}\text { Interior side } \\
\text { column }\end{array}$ & 1206.89 & 1214.12 & 1215.82 & 1217.71 & 1219.81 & 1221.94 & 0.6 & 0.74 & 0.896 & 1.07 & 1.247 \\
\hline 5 & $\begin{array}{l}\text { Interior middle } \\
\text { column }\end{array}$ & 1217.05 & 1224.20 & 1225.91 & 1227.82 & 1229.84 & 1232.02 & 0.59 & 0.73 & 0.88 & 1.05 & 1.23 \\
\hline 6 & Center column & 1226.72 & 1226.72 & 1226.72 & 1226.72 & 1226.72 & 1226.72 & 0 & 0 & 0 & 0 & 0 \\
\hline
\end{tabular}


Table 2: Comparison of support reactions for different wind speeds for G+10:-

\begin{tabular}{|c|c|c|c|c|c|c|c|c|c|c|c|c|}
\hline \multirow{3}{*}{$\begin{array}{l}\text { S. } \\
\text { No }\end{array}$} & \multirow{3}{*}{$\begin{array}{l}\text { Location of } \\
\text { column }\end{array}$} & \multicolumn{6}{|c|}{ Support reaction $(\mathrm{kN})$ for different wind speeds } & \multirow{2}{*}{\multicolumn{5}{|c|}{$\begin{array}{l}\text { Increase of support reactions in percentage } \\
\text { for wind speeds }\end{array}$}} \\
\hline & & \multirow{2}{*}{$\begin{array}{l}\text { DL+L } \\
\mathrm{L} \\
\mathbf{0} \\
\end{array}$} & \multicolumn{5}{|c|}{$\mathrm{DL}+\mathrm{LL}+\mathrm{WL}$} & & & & & \\
\hline & & & 180 & 200 & 220 & 240 & 260 & 180 & 200 & 220 & 240 & 260 \\
\hline 1 & $\begin{array}{l}\text { Exterior } \\
\text { columns }\end{array}$ & $\begin{array}{l}1433.9 \\
4\end{array}$ & $\begin{array}{l}1627.2 \\
5\end{array}$ & $\begin{array}{l}1673.3 \\
7\end{array}$ & $\begin{array}{l}1723.6 \\
9\end{array}$ & $\begin{array}{l}1779.0 \\
1\end{array}$ & $\begin{array}{l}1838.5 \\
9\end{array}$ & $\begin{array}{l}13.52 \\
1\end{array}$ & 16.69 & 20.206 & 24.06 & 28.22 \\
\hline 2 & $\begin{array}{ll}\text { Edge } & \text { side } \\
\text { columns }\end{array}$ & $\begin{array}{l}1807.7 \\
5\end{array}$ & $\begin{array}{l}2001.6 \\
6\end{array}$ & $\begin{array}{l}2047.1 \\
8\end{array}$ & $\begin{array}{l}2097.5 \\
1\end{array}$ & $\begin{array}{l}2152.8 \\
2\end{array}$ & $\begin{array}{l}2212.4 \\
1\end{array}$ & $\begin{array}{l}10.72 \\
6\end{array}$ & 13.244 & 16.028 & 19.09 & 22.38 \\
\hline 3 & $\begin{array}{l}\text { Edge middle } \\
\text { columns }\end{array}$ & $\begin{array}{l}1863.3 \\
5\end{array}$ & $\begin{array}{l}2057.2 \\
5\end{array}$ & $\begin{array}{l}2102.7 \\
7\end{array}$ & $\begin{array}{l}2153.0 \\
9\end{array}$ & $\begin{array}{l}2208.4 \\
1\end{array}$ & $\begin{array}{l}2268.0 \\
0\end{array}$ & $\begin{array}{l}10.40 \\
6\end{array}$ & 12.848 & 15.55 & 18.52 & 21.71 \\
\hline 4 & $\begin{array}{l}\text { Interior side } \\
\text { columns }\end{array}$ & $\begin{array}{l}2178.2 \\
3\end{array}$ & $\begin{array}{l}2188.0 \\
1\end{array}$ & $\begin{array}{l}2190.2 \\
9\end{array}$ & $\begin{array}{l}2192.8 \\
3\end{array}$ & $\begin{array}{l}2195.6 \\
2\end{array}$ & $\begin{array}{l}2198.6 \\
2\end{array}$ & 0.448 & 0.553 & 0.67 & 0.798 & 0.936 \\
\hline 5 & $\begin{array}{l}\text { Interior middle } \\
\text { columns }\end{array}$ & $\begin{array}{l}2232.5 \\
8\end{array}$ & $\begin{array}{l}2242.3 \\
4\end{array}$ & $\begin{array}{l}2244.6 \\
4\end{array}$ & $\begin{array}{l}2247.1 \\
7\end{array}$ & $\begin{array}{l}2249.9 \\
6\end{array}$ & $\begin{array}{l}2252.9 \\
6\end{array}$ & 0.437 & 0.54 & 0.653 & 0.778 & 0.912 \\
\hline 6 & Center column & $\begin{array}{l}2286.5 \\
7\end{array}$ & $\begin{array}{l}2286.5 \\
7\end{array}$ & $\begin{array}{l}2286.5 \\
7\end{array}$ & $\begin{array}{l}2286.5 \\
7\end{array}$ & $\begin{array}{l}2286.5 \\
7\end{array}$ & $\begin{array}{l}2286.5 \\
7\end{array}$ & 0 & 0 & 0 & 0 & 0 \\
\hline
\end{tabular}

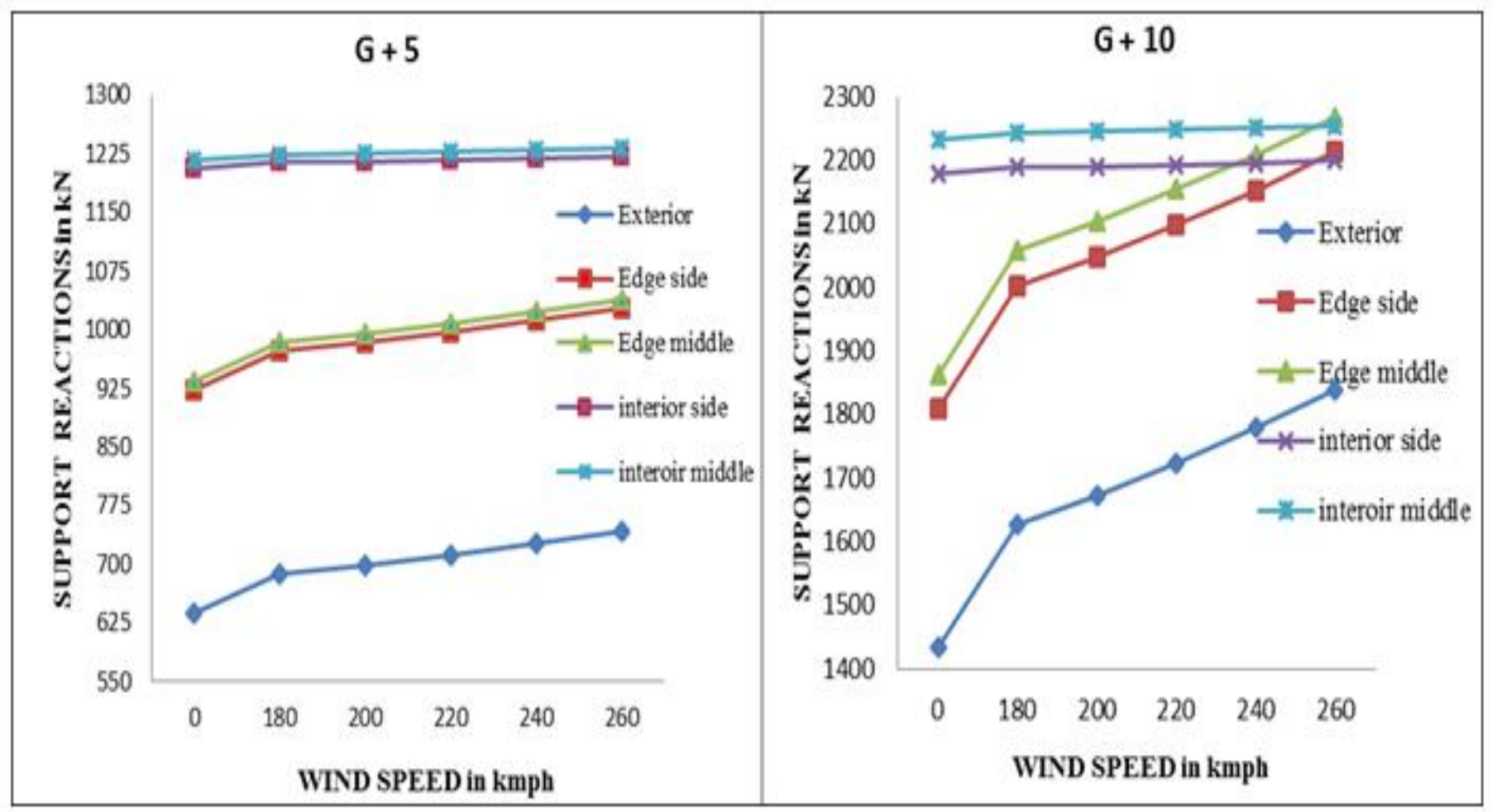

Fig 5: Comparison of support reactions of columns for different wind speeds

Here 180, 200, 220, 240, 260 are wind speeds are in kmph.

\section{Support Reactions Variation with 180kmph Wind Speed:-}

If the structure is situated in coastal region, the wind load should be considered for buildings higher than $10 \mathrm{~m}$. The basic wind speed for coastal region as per IS: 875 - part (3) is $50 \mathrm{~m} / \mathrm{s}(180 \mathrm{kmph})$. Considering this wind load in design the comparison is made with $180 \mathrm{kmph}$ to other wind speeds. 
Table 3: Comparison of support reactions for different wind speeds with $180 \mathrm{kmph}$ wind:-

\begin{tabular}{|l|l|l|l|l|l|l|l|l|l|}
\hline \multirow{2}{*}{$\begin{array}{l}\text { S. } \\
\text { No. }\end{array}$} & \multirow{2}{*}{$\begin{array}{l}\text { Location of column } \\
\end{array}$} & \multicolumn{2}{|l|}{$\begin{array}{l}\text { For G+5, Increase of support reactions } \\
\text { variation in percentage for different wind } \\
\text { speeds in kmph }\end{array}$} & \multicolumn{3}{|l|}{$\begin{array}{l}\text { For G+10, Increase of support reactions in } \\
\text { percentage for different wind speeds in kmph }\end{array}$} \\
\cline { 3 - 11 } & $\mathbf{2 0 0}$ & $\mathbf{2 2 0}$ & $\mathbf{2 4 0}$ & $\mathbf{2 6 0}$ & $\mathbf{2 0 0}$ & $\mathbf{2 2 0}$ & $\mathbf{2 4 0}$ & $\mathbf{2 6 0}$ \\
\hline 1 & Exterior columns & 1.731 & 3.636 & 5.69 & 7.962 & 2.834 & 5.926 & 9.326 & 12.987 \\
\hline 2 & Edge side columns & 1.22 & 2.57 & 4.026 & 5.629 & 2.274 & 4.788 & 7.552 & 10.528 \\
\hline 3 & Edge middle columns & 1.199 & 2.534 & 3.953 & 5.563 & 2.212 & 4.658 & 7.347 & 10.244 \\
\hline 4 & Interior side column & 0.14 & 1.128 & 1.295 & 1.474 & 0.104 & 0.221 & 0.348 & 0.485 \\
\hline 5 & $\begin{array}{l}\text { Interior } \\
\text { column }\end{array}$ & 0.139 & 0.296 & 0.461 & 0.638 & 0.102 & 0.215 & 0.339 & 0.473 \\
\hline 6 & Center column & 0 & 0 & 0 & 0 & 0 & 0 & 0 & 0 \\
\hline
\end{tabular}

\section{COLUMN LONGITUDINAL REINFORCEMENTS}

Table 4: The corner column reinforcement percentage for $\mathrm{G}+5$ building for different wind speeds:-

\begin{tabular}{|c|c|c|c|c|c|c|c|}
\hline \multirow{3}{*}{$\begin{array}{l}\text { Location of } \\
\text { columns }\end{array}$} & \multicolumn{7}{|c|}{ Percentage of steel reinforcement in columns } \\
\hline & \multicolumn{7}{|c|}{\begin{tabular}{l|l}
$\mathrm{DL}+\mathrm{LL}$ & $\mathrm{DL}+\mathrm{LL}+\mathrm{WL}$ \\
\end{tabular}} \\
\hline & 0 & 180 & 200 & 220 & 240 & 260 & Wind(kmph) \\
\hline Exterior & 0.80 & 0.80 & 0.80 & 0.8 & 0.80 & 0.80 & \multirow{3}{*}{$2^{\text {nd }}$ floor } \\
\hline Edge & 0.97 & 0.97 & 0.97 & 1.08 & 0.80 & 0.95 & \\
\hline Interior & 1.05 & 1.05 & 1.05 & 1.14 & 0.80 & 0.90 & \\
\hline Exterior & 1.16 & 2.40 & 2.79 & 3.24 & 1.62 & 1.87 & \multirow{3}{*}{ Ground floor } \\
\hline Edge & 2.94 & 2.99 & 2.99 & 3.35 & 1.49 & 1.76 & \\
\hline Interior & 3.08 & 3.08 & 3.08 & 3.22 & 1.43 & 1.70 & \\
\hline
\end{tabular}

In the above table the column size is $300 \mathrm{~mm} \times 300 \mathrm{~mm}$ for wind speeds up to $220 \mathrm{kmph}, 350 \mathrm{~mm} \times 350 \mathrm{~mm}$ column size for wind speeds $240 \mathrm{kmph}$ and $260 \mathrm{kmph}$.

Table 5: Comparison of percentage of steel in columns for different winds for G+10:-

\begin{tabular}{|c|c|c|c|c|c|c|c|}
\hline \multirow{3}{*}{$\begin{array}{l}\text { Location of } \\
\text { columns }\end{array}$} & \multicolumn{7}{|c|}{ Percentage of steel reinforcement in columns } \\
\hline & \multirow{2}{*}{$\frac{\mathrm{DL}+\mathrm{LL}}{0}$} & \multicolumn{6}{|c|}{$\mathrm{DL}+\mathrm{LL}+\mathrm{WL}$} \\
\hline & & 180 & 200 & 220 & 240 & 260 & Wind(kmph) \\
\hline Exterior & 0.80 & 0.80 & 0.80 & 0.80 & 0.80 & 0.80 & \multirow{3}{*}{ 6th floor } \\
\hline Edge & 0.80 & 0.80 & 0.80 & 0.80 & 0.80 & 0.80 & \\
\hline Interior & 0.80 & 0.80 & 0.80 & 0.80 & 0.80 & 0.80 & \\
\hline Exterior & 0.80 & 1.25 & 1.48 & 1.69 & 0.92 & 1.17 & \multirow{3}{*}{$3^{\text {rd }}$ floor } \\
\hline Edge & 1.23 & 1.43 & 1.61 & 1.80 & 0.91 & 1.15 & \\
\hline Interior & 1.81 & 1.44 & 1.64 & 1.83 & 0.86 & 1.11 & \\
\hline Exterior & 1.54 & 2.61 & 2.94 & 3.44 & 2.54 & 2.87 & \multirow{3}{*}{ Ground floor } \\
\hline Edge & 2.38 & 2.95 & 3.34 & 3.75 & 2.64 & 2.95 & \\
\hline Interior & 3.69 & 2.87 & 3.15 & 3.50 & 2.25 & 2.54 & \\
\hline
\end{tabular}

In the above table the column size is $400 \mathrm{~mm} \times 400 \mathrm{~mm}$ for wind speeds up to $220 \mathrm{kmph}, 450 \mathrm{~mm} \times 450 \mathrm{~mm}$ column size for wind speeds $240 \mathrm{kmph}$ and $260 \mathrm{kmph}$.

\section{BEAM REINFORCEMENT VARIATIONS}

Table 6: Comparison of weight of steel in beams for different wind speeds for G+5:-

\begin{tabular}{|l|l|l|l|l|l|l|}
\hline \multirow{2}{*}{ Beams } & \multicolumn{4}{l|}{ Weight of steel in beams for different wind speeds $(\mathrm{kg})$} \\
\cline { 2 - 8 } & DL+LL & $180 \mathrm{kmph}$ & $200 \mathrm{kmph}$ & $220 \mathrm{kmph}$ & $240 \mathrm{kmph}$ & $260 \mathrm{kmph}$ \\
\hline External Beams & 128 & 187 & 198 & 218 & 232 & 246 \\
\hline Internal Beams & 240 & 333 & 346 & 358 & 368 & 390 \\
\hline Total & 368 & 520 & 544 & 576 & 600 & 636 \\
\hline \% difference with 180kmph & - & 0 & 4.615 & 10.77 & 15.385 & 22.307 \\
\hline
\end{tabular}




\section{STOREY DISPLACEMENTS}

Table 7: Lateral storey displacements for G+5:-

\begin{tabular}{|l|l|l|l|l|l|l|}
\hline \multirow{2}{*}{ Story } & \multirow{2}{*}{$\begin{array}{l}\text { Elevation } \\
(\mathrm{m})\end{array}$} & $\begin{array}{l}\text { Wind Direction Displacements for different wind } \\
\text { Speeds (mm) }\end{array}$ \\
\cline { 3 - 7 } & & 180 & 200 & 220 & 240 & 260 \\
\hline $\mathrm{G}+5$ & 20 & 15.6 & 19.3 & 23.4 & 27.8 & 32.7 \\
\hline $\mathrm{G}+4$ & 17 & 15.1 & 18.6 & 22.6 & 26.8 & 31.5 \\
\hline $\mathrm{G}+3$ & 14 & 13.8 & 17.0 & 20.7 & 24.5 & 28.8 \\
\hline $\mathrm{G}+2$ & 11 & 11.8 & 14.5 & 17.6 & 20.9 & 24.6 \\
\hline G+1 & 8 & 9.0 & 11.1 & 13.5 & 16.0 & 18.8 \\
\hline Ground & 5 & 5.6 & 6.9 & 8.4 & 9.9 & 11.7 \\
\hline Plinth & 2 & 1.5 & 1.8 & 2.2 & 2.6 & 3.1 \\
\hline Base & 0 & 0 & 0 & 0 & 0 & 0 \\
\hline
\end{tabular}

Here all columns are of size $300 \mathrm{~mm} \times 300 \mathrm{~mm}$.
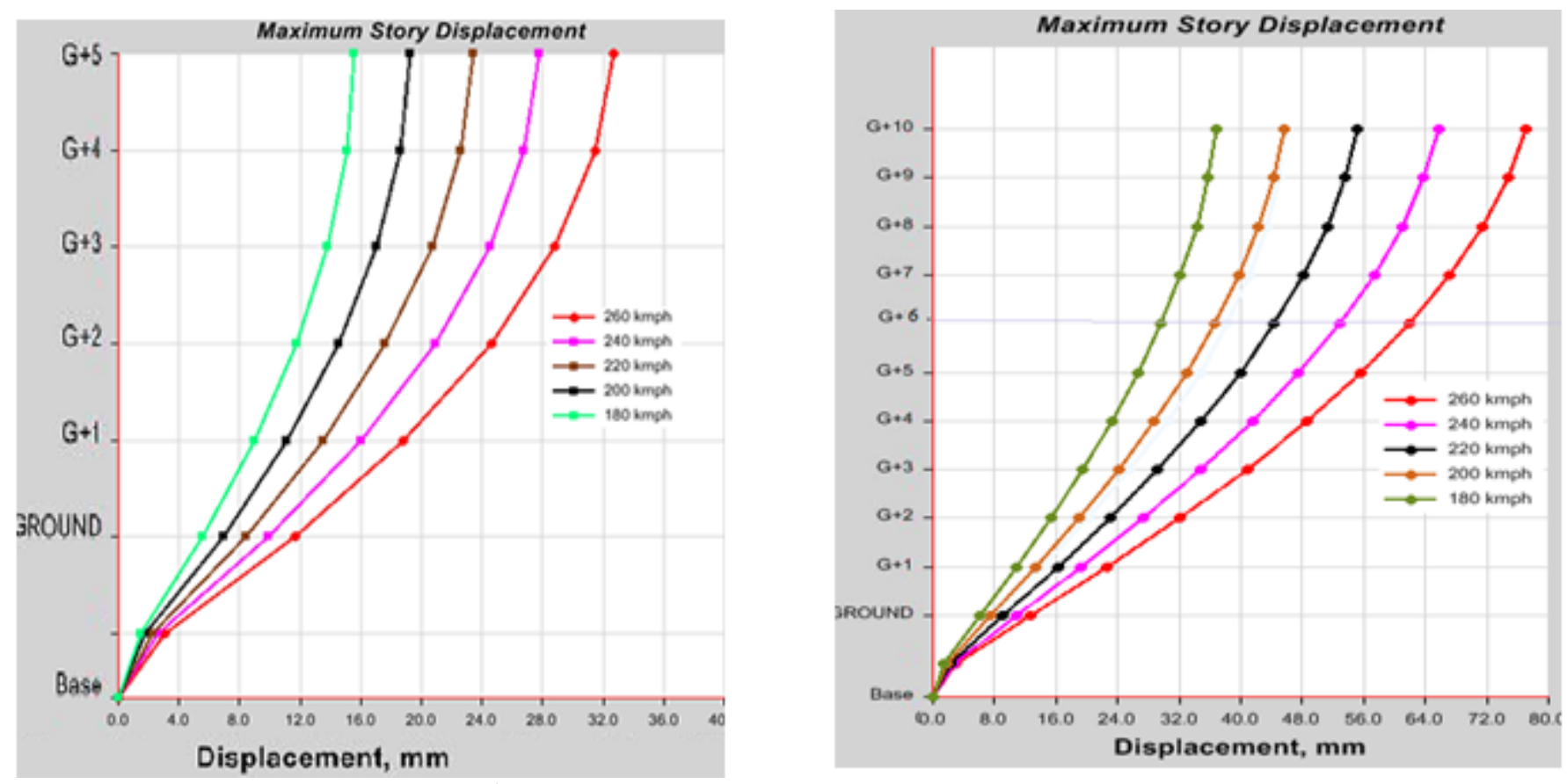

Fig 6: Lateral storey displacements of the structure

Table 8: Lateral storey displacements for $\mathrm{G}+10$ :-

\begin{tabular}{|l|l|l|l|l|l|l|}
\hline \multirow{2}{*}{ Story } & \multirow{6}{*}{$\begin{array}{l}\text { Elevation } \\
(\mathrm{m})\end{array}$} & $\begin{array}{l}\text { Wind Direction Displacements for different wind } \\
\text { Speeds (mm) }\end{array}$ \\
\cline { 3 - 7 } & & 180 & 200 & 220 & 240 & 260 \\
\hline $\mathrm{G}+10$ & 35 & 36.9 & 45.6 & 55.2 & 65.7 & 77.1 \\
\hline $\mathrm{G}+9$ & 32 & 35.8 & 44.3 & 53.6 & 63.8 & 74.8 \\
\hline $\mathrm{G}+8$ & 29 & 34.3 & 42.3 & 51.2 & 61 & 71.5 \\
\hline $\mathrm{G}+7$ & 26 & 32.2 & 39.7 & 48.1 & 57.3 & 67.2 \\
\hline $\mathrm{G}+6$ & 23 & 29.7 & 36.6 & 44.3 & 52.8 & 61.9 \\
\hline $\mathrm{G}+5$ & 20 & 26.7 & 33 & 39.9 & 47.5 & 55.7 \\
\hline $\mathrm{G}+4$ & 17 & 23.3 & 28.8 & 34.8 & 41.5 & 48.7 \\
\hline $\mathrm{G}+3$ & 14 & 19.5 & 24.1 & 29.2 & 34.8 & 40.8 \\
\hline
\end{tabular}




\begin{tabular}{|l|l|l|l|l|l|l|}
\hline $\mathrm{G}+2$ & 11 & 15.4 & 19 & 23 & 27.3 & 32.1 \\
\hline $\mathrm{G}+1$ & 8 & 10.9 & 13.4 & 16.2 & 19.3 & 22.7 \\
\hline Ground & 5 & 6.1 & 7.5 & 9.1 & 10.8 & 12.7 \\
\hline Plinth & 2 & 1.4 & 1.8 & 2.2 & 2.6 & 3 \\
\hline Base & 0 & 0 & 0 & 0 & 0 & 0 \\
\hline
\end{tabular}

Here all columns are of size $400 \mathrm{~mm} \times 400 \mathrm{~mm}$.

\section{STOREY DRIFTS}

Table 9: Storey drifts for G+5:-

\begin{tabular}{|l|l|l|l|l|l|l|}
\hline \multirow{2}{*}{ Story } & \multirow{2}{*}{$\begin{array}{l}\text { Elevation } \\
(\mathrm{m})\end{array}$} & \multicolumn{6}{l}{ Wind Direction Storey drifts for different wind speeds } \\
\cline { 3 - 7 } & & $180 \mathrm{kmph}$ & $200 \mathrm{kmph}$ & $220 \mathrm{kmph}$ & $240 \mathrm{kmph}$ & $260 \mathrm{kmph}$ \\
\hline $\mathrm{G}+5$ & 20 & 0.000183 & 0.000226 & 0.000274 & 0.000235 & 0.000277 \\
\hline $\mathrm{G}+4$ & 17 & 0.000429 & 0.00053 & 0.000642 & 0.00053 & 0.000623 \\
\hline G+3 & 14 & 0.000677 & 0.000838 & 0.001015 & 0.000837 & 0.000984 \\
\hline G+2 & 11 & 0.000914 & 0.00113 & 0.001369 & 0.00113 & 0.001328 \\
\hline G+1 & 8 & 0.001144 & 0.001415 & 0.001714 & 0.001414 & 0.001662 \\
\hline Ground & 5 & 0.001374 & 0.001699 & 0.002059 & 0.001671 & 0.001964 \\
\hline Plinth & 2 & 0.00073 & 0.000903 & 0.001094 & 0.000885 & 0.00104 \\
\hline Base & 0 & 0 & 0 & 0 & 0 & \\
\hline
\end{tabular}

Table 10: Storey drifts of G+10:-

\begin{tabular}{|l|l|l|l|l|l|l|}
\hline \multirow{2}{*}{ Story } & \multirow{2}{*}{$\begin{array}{l}\text { Elevation } \\
(\mathrm{m})\end{array}$} & \multicolumn{2}{l}{ Wind Direction Storey drifts for different wind speeds } \\
\cline { 3 - 7 } & & $180 \mathrm{kmph}$ & $200 \mathrm{kmph}$ & $220 \mathrm{kmph}$ & $240 \mathrm{kmph}$ & $260 \mathrm{kmph}$ \\
\hline $\mathrm{G}+10$ & 35 & 0.00037 & 0.000456 & 0.000552 & 0.000547 & 0.000641 \\
\hline $\mathrm{G}+9$ & 32 & 0.000529 & 0.000653 & 0.000791 & 0.000786 & 0.000922 \\
\hline $\mathrm{G}+8$ & 29 & 0.000687 & 0.000849 & 0.001027 & 0.001024 & 0.001201 \\
\hline G+7 & 26 & 0.000841 & 0.001038 & 0.001256 & 0.001256 & 0.001473 \\
\hline G+6 & 23 & 0.000988 & 0.00122 & 0.001476 & 0.001479 & 0.001735 \\
\hline G+5 & 20 & 0.001129 & 0.001394 & 0.001687 & 0.001693 & 0.001986 \\
\hline G+4 & 17 & 0.001262 & 0.001559 & 0.001886 & 0.001896 & 0.002224 \\
\hline G+3 & 14 & 0.001388 & 0.001713 & 0.002073 & 0.002086 & 0.002446 \\
\hline G+2 & 11 & 0.001502 & 0.001855 & 0.002244 & 0.002256 & 0.002646 \\
\hline G+1 & 8 & 0.001596 & 0.00197 & 0.002385 & 0.002377 & 0.002787 \\
\hline Ground & 5 & 0.001543 & 0.001906 & 0.002306 & 0.002222 & 0.002606 \\
\hline Plinth & 2 & 0.000722 & 0.000892 & 0.001079 & 0.001019 & 0.001195 \\
\hline Base & 0 & 0 & 0 & 0 & 0 & 0 \\
\hline
\end{tabular}

\section{STOREY SHEARS:}

Table 11: Storey shears of G+5:-

\begin{tabular}{|c|c|c|c|c|c|}
\hline \multirow{2}{*}{ Storey } & \multicolumn{5}{|c|}{ Storey shear $(\mathrm{kN})$ for different wind speeds } \\
\hline & 180 & 200 & 220 & 240 & 260 \\
\hline $\mathrm{G}+5$ & 47.62 & 58.89 & 71.35 & 84.75 & 99.58 \\
\hline $\mathrm{G}+4$ & 139.64 & 172.67 & 209.21 & 248.51 & 291.98 \\
\hline $\mathrm{G}+3$ & 228.13 & 282.09 & 341.78 & 405.97 & 477.00 \\
\hline $\mathrm{G}+2$ & 312.47 & 386.38 & 468.13 & 556.06 & 653.35 \\
\hline $\mathrm{G}+1$ & 395.45 & 488.99 & 592.45 & 703.72 & 826.85 \\
\hline Ground & 478.43 & 591.59 & 716.76 & 851.38 & 1000.33 \\
\hline Plinth & 547.57 & 677.10 & 820.36 & 974.44 & 1144.97 \\
\hline Base & 0 & 0 & 0 & 0 & 0 \\
\hline
\end{tabular}


Table 12: Storey shears of G+10:-

\begin{tabular}{|l|l|l|l|l|l|}
\hline \multirow{2}{*}{ Storey } & \multicolumn{5}{l}{ Storey shear $(\mathrm{kN})$ for different wind speeds } \\
\cline { 2 - 6 } & 180 & 200 & 220 & 240 & 260 \\
\hline G+10 & 53.47 & 66.02 & 79.89 & 95.15 & 111.58 \\
\hline G+9 & 158.96 & 196.28 & 237.53 & 282.88 & 331.74 \\
\hline G+8 & 262.56 & 324.20 & 392.33 & 467.24 & 547.93 \\
\hline G+7 & 363.34 & 448.63 & 542.92 & 646.58 & 758.23 \\
\hline G+6 & 461.33 & 569.64 & 689.35 & 820.97 & 962.74 \\
\hline G+5 & 556.59 & 687.26 & 831.69 & 990.48 & 1161.53 \\
\hline G+4 & 648.61 & 800.88 & 969.19 & 1154.23 & 1353.56 \\
\hline G+3 & 737.09 & 910.14 & 1101.41 & 1311.70 & 1538.22 \\
\hline G+2 & 821.43 & 1014.28 & 1227.43 & 1461.78 & 1714.22 \\
\hline G+1 & 904.41 & 1116.73 & 1351.43 & 1609.45 & 1887.39 \\
\hline Ground & 987.39 & 1219.19 & 1475.42 & 1757.11 & 2060.55 \\
\hline Plinth & 1056.54 & 1304.58 & 1578.74 & 1880.17 & 2204.86 \\
\hline Base & 0 & 0 & 0 & 0 & 0 \\
\hline
\end{tabular}

COMPARISON OF CONCRETE AND STEEL IN FOOTINGS:-

Table 13: Comparison of quantity of material required for different wind speeds in footings:-

\begin{tabular}{|c|c|c|c|c|c|c|c|c|c|c|c|c|c|c|}
\hline \multirow{3}{*}{$\begin{array}{l}\text { LOCATIO } \\
\text { N OF } \\
\text { COLUMN }\end{array}$} & \multicolumn{7}{|c|}{ Volume of concrete in footings (cu.m) } & \multicolumn{7}{|c|}{ Weight of steel in footings $(\mathrm{kg})$} \\
\hline & \multirow{2}{*}{$\begin{array}{l}\text { DL } \\
+ \\
\text { LL } \\
\text { Gravit } \\
\text { y }\end{array}$} & \multicolumn{3}{|c|}{$\mathbf{D L}+\mathbf{L} \mathbf{L}+\mathbf{W} \mathbf{L}$} & \multicolumn{3}{|c|}{$\begin{array}{l}\text { PERCENTAGE } \\
\text { DIFFERENCE } \\
\text { WITH GRAVITY }\end{array}$} & \multirow{2}{*}{\begin{tabular}{|l} 
DL \\
+ \\
LL \\
Gravit \\
$\mathrm{y}$
\end{tabular}} & \multicolumn{3}{|c|}{$\mathbf{D L}+\mathbf{L L}+\mathbf{W L}$} & \multicolumn{3}{|c|}{$\begin{array}{l}\text { PERCENTAGE } \\
\text { DIFFERENCE } \\
\text { WITH GRAVITY }\end{array}$} \\
\hline & & 180 & 200 & 220 & 180 & 200 & 220 & & 180 & 200 & 220 & 180 & 200 & 220 \\
\hline $\begin{array}{l}\text { Exterior } \\
\text { columns }\end{array}$ & 2.61 & 3.08 & 3.24 & 3.47 & 18.0 & $\begin{array}{l}24.1 \\
4\end{array}$ & $\begin{array}{l}32.9 \\
5\end{array}$ & 86.27 & 98.22 & $\begin{array}{l}107.1 \\
2\end{array}$ & $\begin{array}{l}115.7 \\
8\end{array}$ & $\begin{array}{l}13.8 \\
5\end{array}$ & $\begin{array}{l}24.1 \\
7\end{array}$ & $\begin{array}{l}34.2 \\
1\end{array}$ \\
\hline $\begin{array}{l}\text { Edge } \\
\text { columns }\end{array}$ & 4.54 & 5.18 & 5.38 & 5.53 & $\begin{array}{l}14.0 \\
9\end{array}$ & $\begin{array}{l}18.5 \\
0\end{array}$ & $\begin{array}{l}21.8 \\
1\end{array}$ & 144.47 & $\begin{array}{l}168.7 \\
4\end{array}$ & $\begin{array}{l}175.1 \\
7\end{array}$ & $\begin{array}{l}181.1 \\
6\end{array}$ & $\begin{array}{l}16.7 \\
9\end{array}$ & $\begin{array}{l}21.2 \\
5\end{array}$ & $\begin{array}{l}25.3 \\
9\end{array}$ \\
\hline $\begin{array}{l}\text { Interior } \\
\text { columns }\end{array}$ & 9.65 & $\begin{array}{l}10.1 \\
4\end{array}$ & $\begin{array}{l}10.2 \\
9\end{array}$ & $\begin{array}{l}10.4 \\
5\end{array}$ & $\begin{array}{l}5.07 \\
7\end{array}$ & 6.63 & 8.29 & 324.72 & $\begin{array}{l}347.1 \\
5\end{array}$ & $\begin{array}{l}349.2 \\
2\end{array}$ & $\begin{array}{l}351.2 \\
8\end{array}$ & 6.91 & 7.54 & 8.18 \\
\hline
\end{tabular}

Here for $\mathrm{G}+10$ building, the maximum support reaction for each location of column is considered for footing design.

\section{CONCLUSION}

- In $\mathrm{G}+5$ building, the variation of support reactions in exterior, edge columns increased from 8 to $16 \%, 5.5$ to $11.5 \%$ for wind speeds 180 to $260 \mathrm{kmph}$ respectively when compared with gravity loading. Similarly in $\mathrm{G}+10$ building, the variation of support reactions in exterior, edge columns increases from 13 to $28 \%, 10$ to $22 \%$ and very small in interior columns.

- In $\mathrm{G}+5$ building, the percentage variation of steel in edge, exterior and interior columns varies from 1.2$4.22 \%, 2.1-6.29 \%, 2.9-5.88 \%$ between gravity loads to wind loads for wind speed $260 \mathrm{kmph}$ respectively in ground floor for the column size of $300 \mathrm{~mm} \times 300 \mathrm{~mm}$.
- In G+10 building, the percentage variation of steel in edge, exterior and interior columns varies from $0.8-3.24 \%, 1.24-3.88 \%, 1.8-3.53 \%$ between gravity loads to wind load for speed $260 \mathrm{kmph}$ respectively for the column size of $400 \mathrm{~mm} \times 400 \mathrm{~mm}$.

- In the external and internal beams, the percentage of bottom middle reinforcement is same for both wind and gravity load design.Percentage variation of steel reinforcement in beams is $4.6,10.8,15.4$ and $22.3 \%$ for wind speeds 200, 220, 240 and $260 \mathrm{kmph}$ respectively with $180 \mathrm{kmph}$ wind speed.

- The maximum storey displacement of $\mathrm{G}+5$ building is 15.6 to $22.6 \mathrm{~mm}$ and in $\mathrm{G}+10$ building, it is 30.8 to $53.7 \mathrm{~mm}$ for wind speed $180 \mathrm{kmph}$ to $260 \mathrm{kmph}$.

- It is observed that the percentage variation of cost for the whole structure, between gravity load and 
three different wind speeds varies as $4.98,5.56$ and $6.62 \%$ in 5 storey building and $9.82,11.89$ and $13.52 \%$ in 10 storey building respectively. If the design wind speed exceeds $220 \mathrm{kmph}$ then the load combination 1.5 times of dead load and wind load governs the design of structural members.

\section{REFERENCES}

[1] Swati D.Ambadkar, Vipul S. Bawner "Behaviour of multistoried building under the effect of wind load" Int. Journal of Applied Sciences and Engineering Research, Vol. 1, Issue 4, 2012, ISSN 2277 - 9442

[2] Dr. S.R. Karve\& Dr. V.L. Shah - "Illustrated design of Reinforced concrete Buildings"

[3] Ahsan Kareem, "Along-Wind Load Effects on Tall Buildings" Comparative Study of Major International Codes and Standards, Journal of structural engineering, June 2002

[4] IS 875 (Part 3), 1987, Indian Standard Code of practice for design loads (Other than Earthquake) for buildings and structures (2nd Revision).

[5] IS: 875 (Part 2), "Indian Standard Code of Practice for design loads for building and structures, Live Loads" Bureau of Indian Standards, New Delhi.

[6] IS: 875 (Part 1), "Indian Standard Code of Practice for design loads for building and structures, Dead Loads" Bureau of Indian Standards, New Delhi.

[7] IS 456:2000, "Indian Standard plain and reinforced concrete-Code of Practice", Bureau of Indian Standards, New Delhi, 2000. 